\title{
Effect of dietary formic acid and astaxanthin on the survival and growth of Pacific white shrimp (Litopenaeus vannamei) and their resistance to Vibrio parahaemolyticus
}

\author{
Niti Chuchird*, Phitsanu Rorkwiree and Tirawat Rairat
}

*Correspondence: ffisntc@ ku.ac.th

Faculty of Fisheries,

Aquaculture Business

Research Center, Kasetsart University, Bangkok 10900, Thailand

\begin{abstract}
A 90-day feeding trial was conducted to evaluate the effects of formic acid (FA) and astaxanthin (AX) on growth, survival, immune parameters, and tolerance to Vibrio infection in Pacific white shrimp. The study was divided into two experiments. In experiment 1, postlarvae-12 were randomly distributed into six groups and then fed four times daily with six experimental diets contained $0.3 \%$ FA, $0.6 \%$ FA, 50 ppm AX, $0.3 \% \mathrm{FA}+50 \mathrm{ppm} \mathrm{AX}, 0.6 \% \mathrm{FA}+50 \mathrm{ppm} \mathrm{AX}$, or none of these supplements (control diet). After 60 days of the feeding trials, the body weight of all treatment groups was not significantly different from the control group, although shrimp fed formic acid had significantly lower body weight than shrimp fed 50 ppm AX. However, the $0.6 \%$ $\mathrm{FA}+50 \mathrm{ppm}$ AX group had a significantly higher survival rate $(82.33 \pm 8.32 \%)$ than the control group (64.33 $\pm 10.12 \%)$. In experiment 2, Vibrio parahaemolyticus was added to each tank to obtain a final concentration of $10^{4}$ colony-forming units $/ \mathrm{mL}$. Each treatment group received the aforementioned diets for another 30 days. At the end of this experiment, there was no difference in the weight gain among all experimental groups. However, the survival rate of shrimps whose diet included FA, AX, and their combination (in the range of 45.83-67.50 \%) was significantly higher than the control group (20.00 $\pm 17.32 \%)$. FA-fed shrimps also had significantly lower total intestinal bacteria and Vibrio spp. counts, while immune parameters [total hemocyte count (THC), phagocytosis activity, phenoloxidase (PO) activity, and superoxide dismutase (SOD) activity] of AX-fed groups were significantly improved compared with the other groups. In conclusion, FA, AX, and their combination are useful in shrimp aquaculture.
\end{abstract}

Keywords: Astaxanthin, Formic acid, Pacific white shrimp, Vibrio parahaemolyticus

\section{Background}

Pacific white shrimp (Litopenaeus vannamei) is the primary shrimp species cultured in many Asian countries, including Thailand (Limsuwan and Chanratchakool 2004). Since 2012, Thai shrimp farmers have suffered major economic losses owing to Early Mortality Syndrome (EMS). The disease reduced shrimp production of Thailand from 5,40,000 tons in 2012 to 2,56,000 tons in 2013 and 2,10,000 tons in 2014, respectively (Office of Agricultural Economics 2014; Tangtong 2015). Affected shrimp show signs of a pale

(C) 2015 Chuchird et al. This article is distributed under the terms of the Creative Commons Attribution 4.0 International License (http://creativecommons.org/licenses/by/4.0/), which permits unrestricted use, distribution, and reproduction in any medium, provided you give appropriate credit to the original author(s) and the source, provide a link to the Creative Commons license, and indicate if changes were made. 
coloration owing to pigment loss, as well as an atrophied hepatopancreas. These signs may become apparent as early as 4 days after stocking (Munkongwongsiri et al. 2013). Vibrio parahaemolyticus is the suspected agent that causes mass mortality as it induced $100 \%$ mortality with typical EMS pathology to experimental shrimp (Tran et al. 2013). Because the usage of antibiotics in shrimp aquaculture is discouraged, it is necessary to find an alternative solution to prevent bacterial infection. Organic acids are among the most promising substances as they have been reported to possess anti-Vibrio spp. activities (Mine and Boopathy 2011; Adams and Boopathy 2013; da Silva et al. 2013), and increased survival rate of shrimps (Walla et al. 2012; Su et al. 2014; Romano et al. 2015; $\mathrm{Ng}$ et al. 2015). Astaxanthin, a type of carotenoid, can also improve shrimp survival rate and enhance resistance to several stress conditions, such as low dissolved oxygen, low salinity, low temperature, and ammonia stress (Chien et al. 2003; Pan et al. 2003; Chien and Shiau 2005; Flores et al. 2007; Niu et al. 2009). Therefore, both organic acids and astaxanthin have the potential to be used in shrimp farming as feed additives. The objectives of this study were to evaluate the effect of dietary supplementation of formic acid and astaxanthin on growth, survival and tolerance to $V$. parahaemolyticus infection in Pacific white shrimp under laboratory conditions. The effects of these substances on total intestinal bacterial counts, intestinal Vibrio spp. counts, and some immune parameters of shrimp were also examined.

\section{Methods}

Experiment 1 The effects of formic acid and astaxanthin on growth and survival of Pacific white shrimp postlarvae.

\section{Experimental diets}

Formic acid (FA) and astaxanthin (AX) used in this study were Amasil ${ }^{\circledR}$ NA (94 \% formic acid, BASF The Chemical Company, Germany) and Lucantin Pink ${ }^{\circledR}$ CWD (10 \% astaxanthin, BASF The Chemical Company, Germany). Six experimental diets were formulated; 0.3 \% FA, 0.6 \% FA, 50 ppm AX, 0.3 \% FA + 50 ppm AX, 0.6 \% FA + 50 ppm AX, or none of these supplements (control diet). Both substances were applied by spraying and mixing with commercial pellet feed containing $36 \%$ crude protein and $6 \%$ lipid from Charoen Pokphand, Thailand.

\section{Shrimps and experimental protocol}

The experiments were carried out at the Aquaculture Business Research Center Laboratory, Faculty of Fisheries, Kasetsart University, Thailand. Postlarvae-9 (PL-9) of Pacific white shrimp were obtained from a hatchery in Chachoengsao Province, Thailand. After 3 days of acclimation, shrimps (PL-12) were randomly distributed into $24 \times 500$-L fiberglass tanks (four replicate tanks per treatment). Each tank was stocked with 75 shrimp. Each treatment group was fed with one of the six diets four times daily to satiation for 60 days. Salinity throughout the experiment was maintained at $25 \mathrm{ppt}$, dissolved oxygen above $4 \mathrm{ppm}$, and water temperature at $29 \pm 1{ }^{\circ} \mathrm{C}$. Leftover feed and feces were siphoned daily, and $10 \%$ of the water was exchanged every 3 days. The average body weight and survival rate of shrimp were recorded after a 60-day experimental period. 
Ten shrimps from each tank were randomized and weighted individually by two-decimal point balance.

Experiment 2 The effects of formic acid and astaxanthin on growth, survival, intestinal bacteria, and immune responses of Pacific white shrimps challenged with Vibrio parahaemolyticus.

\section{Shrimps and experimental protocol}

Shrimps from each tank in experiment 1 were randomly distributed into new $24 \times 500-\mathrm{L}$ fiberglass tanks (four replicate tanks per treatment). The stocking density was 30 shrimps per tank. At the beginning of this experiment ( 0 day), Vibrio parahaemolyticus was added into each tank to obtain final concentration of $10^{4}$ colony-forming units $(\mathrm{CFU}) / \mathrm{mL}$, which is the normal concentration of Vibrio in the water of shrimp farm as described by Sung et al. (2001) and Lavilla-Pitogo et al. (1998). V. parahaemolyticus used for immersion challenge test in this study was collected from the EMS farm in Thailand using method described by Joshi et al. (2014). Each treatment group received the same diet as in experiment 1 four times daily for another 30 days. Salinity, dissolved oxygen, and water temperature were maintained as in the experiment 1 . Leftover feed and feces were siphoned every 2 days.

\section{Growth and survival study}

The weight of shrimp from each treatment was measured and their survival rate was recorded on the 30th day after being challenged with V. parahaemolyticus at $10^{4} \mathrm{CFU} /$ $\mathrm{mL}$.

\section{Intestinal bacterial study}

Five shrimp from each group were randomized and their intestines collected on the 10th, 20th, and 30th day. The intestine of each shrimp was homogenized and spread on TCBS (selective media for Vibrio spp. culture) or NA (general media for most bacterial cultures) by the spread plate technique, then incubated at $37^{\circ} \mathrm{C}$ for $24 \mathrm{~h}$. Finally, all colonies of bacteria were counted and calculated as $\mathrm{CFU} / \mathrm{g}$ unit.

\section{Immune parameters study}

The immune parameters were measured at the end of the feeding trial. Ten shrimp per treatment were used for immunological tests. A hemolymph sample of $250 \mu \mathrm{L}$ from each shrimp was withdrawn from the base of the 3rd walking leg using a syringe containing $750 \mu \mathrm{L}$ of precooled $\left(4^{\circ} \mathrm{C}\right)$ anticoagulant $(0.114 \mathrm{M}$ trisodium citrate, $450 \mathrm{mM} \mathrm{NaCl}$, $10 \mathrm{mM} \mathrm{KCl}, 10 \mathrm{mM}$ HEPES at pH 7.4) (Nonwachai et al. 2010). The hemolymph-anticoagulant mixture was used to measure total hemocyte count (THC), phagocytosis activity, phenoloxidase (PO) activity, superoxide dismutase (SOD) activity, and bactericidal activity.

1. Total hemocyte count

After collecting hemolymph, hemocytes were counted using a hemocytometer and calculated as THC $($ cells $/ \mathrm{mL})=$ count $\times 10^{4} \times$ dilution factor. 


\section{Phagocytosis activity}

Phagocytotic activity was determined according to Itami et al. (1994). Collected shrimp hemocytes were rinsed with shrimp saline (a solution of $\mathrm{NaCl} 28.4 \mathrm{~g}$, $\mathrm{MgCl}_{2} \cdot 6 \mathrm{H}_{2 \mathrm{O}} 1.0 \mathrm{~g}, \mathrm{MgSO} 4 \cdot 7 \mathrm{H}_{2 \mathrm{O}} 2.0 \mathrm{~g}, \mathrm{CaCl}_{2} \cdot 2 \mathrm{H}_{2 \mathrm{O}} 2.25 \mathrm{~g}, \mathrm{KCl} 0.7 \mathrm{~g}$, glucose $1.0 \mathrm{~g}$, and HEPES $2.38 \mathrm{~g} / \mathrm{L}$ ) and the viable cell number adjusted to $1 \times 10^{6}$ cells $/ \mathrm{mL}$. The cell suspension $(200 \mu \mathrm{L})$ was inoculated onto a cover slip. After $20 \mathrm{~min}$, the cell suspension was removed and rinsed with shrimp saline three times. Heat-killed yeast preparation $(2 \mathrm{~mL})$ was added and incubated for $2 \mathrm{~h}$. Next, the heat-killed yeast preparation was removed and the cell suspension rinsed with shrimp saline five times to reach a concentration of $5 \times 10^{8}$ cells $/ \mathrm{mL}$, and fixed with $100 \%$ methanol. Then, the cover slip was stained with Giemsa stain and mounted with Permount slide mounting fluid. Two hundred hemocytes were counted for each sample. Phagocytic activity, defined as percentage phagocytosis was expressed as:

Percentage phagocytosis $=($ phagocytic hemocytes $/$ total hemocytes $) \times 100$

\section{Phenoloxidase activity}

Phenoloxidase activity was measured spectrophotometrically by recording the formation of dopachrome produced from l-dihydroxyphenylalanine, following a modification of a published protocol (Supamattaya et al. 2000). The hemolymph-anticoagulant mixture was washed three times with shrimp saline and centrifuged at $1000 \mathrm{rpm}$ and $4{ }^{\circ} \mathrm{C}$ for $10 \mathrm{~min}$. Hemocyte lysate was prepared from hemocytes in cacodylate buffer ( $\mathrm{pH}$ 7.4; $0.01 \mathrm{M}$ sodium cacodylate, $0.45 \mathrm{M}$ sodium chloride, $0.01 \mathrm{M}$ calcium chloride, and $0.26 \mathrm{M}$ magnesium chloride; $\mathrm{pH}$ 7.0) by using a sonicator at 30 amplitude for $5 \mathrm{~s}$, and the suspension was then centrifuged at $10,000 \mathrm{rpm}$ at $4{ }^{\circ} \mathrm{C}$ for $20 \mathrm{~min}$ and the supernatant collected. Then $200 \mu \mathrm{L}$ of $0.25 \%$ trypsin in cacodylate buffer was mixed into the $200 \mu \mathrm{L}$ of hemocyte lysate followed by $200 \mu \mathrm{L}$ of l-dihydroxyphenylalanine at $4 \mathrm{mg} / \mathrm{mL}$ as substrate. Enzyme activity was measured as the absorbance of dopachrome at $490 \mathrm{~nm}$ wavelength. The protein content in hemocyte lysate was measured following a published protocol (Lowry et al. 1951). The phenoloxidase activity was calculated as the increase in optimum density per minute per milligram of protein.

4. Superoxide dismutase activity

SOD activity was measured by its ability to inhibit superoxide radical-dependent reactions using a Ransod Kit (Randox, Crumlin, UK). This method is based on the formation of red formazan during a reaction of 2-(4-iodophenyl)-3-(4-nitrophenol)5 -phenyltetrazolium chloride (INT) and superoxide radical, which is assayed in a spectrophotometer at $505 \mathrm{~nm}$. The reaction mixture $(1.7 \mathrm{~mL})$ contains $0.05 \mathrm{mM}$ xanthine and $0.025 \mathrm{mM}$ INT dissolved in $50 \mathrm{mM}$ CAPS (pH 10.2) and $0.94 \mathrm{mM}$ EDTA. In the presence of xanthine oxidase, superoxide and uric acid are produced from the xanthine. The superoxide radicals then react with INT to produce a red formazan dye. The hemolymph-anticoagulant mixture was centrifuged at $3000 \mathrm{rpm}$ and $4{ }^{\circ} \mathrm{C}$ for $10 \mathrm{~min}$. Plasma was removed, and the pellet was resuspended with $3 \mathrm{~mL}$ of $0.9 \% \mathrm{NaCl}$ and centrifuged again. The supernatant was discarded, and the pellet was resuspended with $2 \mathrm{~mL}$ of triple distilled water at $4{ }^{\circ} \mathrm{C}$. A $50 \mu \mathrm{L}$ aliquot of resuspended hemocytes was placed in each well of a 96-well plate that contained 200 
$\mu \mathrm{L}$ of reaction mixture. Fifty microliters of xanthine oxidase solution was added to each well, and the absorbance measured at $505 \mathrm{~nm}$ and $37^{\circ} \mathrm{C}$. The rate of reaction was estimated from the absorbance readings of 0.5 and 3 min after adding xanthine oxidase. A reference standard of SOD was supplied with the Ransod Kit. One unit of SOD was defined as the amount required to inhibit the rate of xanthine reduction by $50 \%$. The specific activity was expressed as SOD units $/ \mathrm{mL}$.

5. Bactericidal activity

Bactericidal activity was measured as described by Supamattaya et al. (2000). Serum was separated from the hemocytes of each shrimp sample before diluting in $2.6 \%$ $\mathrm{NaCl}$ at the following ratios: $1: 2,1: 4,1: 8,1: 16$, and $1: 32$. Then $0.5 \mathrm{~mL}$ of each serum dilution was used for the assay. For the negative control, $0.1 \mathrm{~mL}$ of $\mathrm{NaCl}$ was used in the assay. One tenth of a milliliter of Vibrio harveyi suspension $\left(8.2 \times 10^{6} \mathrm{CFU} /\right.$ $\mathrm{mL}$ ) was added to each serum dilution and the control. The treatments were incubated at room temperature for $3 \mathrm{~h}$ before enumerating the bacteria. The results were recorded from a dilution that could decrease $50 \%$ of $V$. harveyi compared with the control.

\section{Statistical analysis}

Results are presented as the mean \pm standard deviation. One way ANOVA and Duncan's New Multiple Range test were used to compare data among treatments. Differences were considered significant if $\mathrm{p}<0.05$.

\section{Results}

Experiment 1 The effects of formic acid and astaxanthin on growth and survival of Pacific white shrimp postlarvae

After 60 days of dietary administration, shrimp fed with $50 \mathrm{ppm} \mathrm{AX}$ had the highest average body weight $(4.45 \pm 0.45 \mathrm{~g})$, followed by shrimp fed with $0.3 \% \mathrm{FA}+50 \mathrm{ppm}$ $\mathrm{AX}(4.38 \pm 0.37 \mathrm{~g}), 0.6 \% \mathrm{FA}+50 \mathrm{ppm} \mathrm{AX}(4.05 \pm 0.21 \mathrm{~g})$ and the control group $(4.18 \pm 0.05 \mathrm{~g})$. However, the body weight of all FA and AX-fed shrimps were not significantly different from the control group. The average survival rate of shrimp fed with $0.6 \%$ FA +50 ppm AX was $82.33 \pm 8.32 \%$ which was highest among all the other groups and significantly higher than the control group $(64.33 \pm 10.12 \%)$ (Additional file 1: Table S1).

Experiment 2 The effects of formic acid and astaxanthin on growth, survival, intestinal bacteria, and immune responses of Pacific white shrimps challenged with Vibrio parahaemolyticus.

At the end of the feeding trial, the average weight gain of $0.3 \% \mathrm{FA}+50 \mathrm{ppm}$ AX-fed shrimp was highest, being $2.97 \pm 0.83 \mathrm{~g}$. Nevertheless, no significant differences among the six experimental groups were observed. The average survival rate of all FA and AXfed shrimps were significantly higher than the control group $(20.00 \pm 17.32 \%)$ and the best result was obtained in the $0.6 \% \mathrm{FA}+50$ ppm AX-fed group (67.50 $\pm 3.33 \%$ ) (Additional file 1: Table S2).

For the intestinal bacterial study, both Vibrio spp. count and total bacterial count of all four FA-fed groups (namely, $0.3 \% \mathrm{FA}, 0.6 \% \mathrm{FA}, 50 \mathrm{ppm} \mathrm{AX}+0.3 \% \mathrm{FA}$, and $50 \mathrm{ppm}$ $\mathrm{AX}+0.6 \% \mathrm{FA}$ ) were significantly lower than the control and the $50 \mathrm{ppm}$ AX-fed groups 
throughout the feeding trial. The lowest intestinal bacterial counts were observed in shrimps with a diet containing the high dose of FA (i.e. $0.6 \%$ FA). On the 30th day of the experiment, the two lowest intestinal Vibrio spp. counts were observed in $50 \mathrm{ppm}$ $\mathrm{AX}+0.6 \% \mathrm{FA}$ and $0.6 \% \mathrm{FA}$ groups $\left(1.30 \pm 0.58\right.$ and $1.60 \pm 0.70 \times 10^{6} \mathrm{CFU} / \mathrm{g}$, respectively), whereas the highest count was in the control group $\left(47.20 \pm 25.40 \times 10^{6}\right.$ CFU/g). Similarly, the two lowest total bacterial counts were in the $0.6 \%$ FA and $50 \mathrm{ppm}$ $\mathrm{AX}+0.6 \%$ FA groups $\left(2.80 \pm 1.30\right.$ and $3.10 \pm 0.70 \times 10^{6} \mathrm{CFU} / \mathrm{g}$, respectively), while the highest count was from the control group $\left(45.00 \pm 27.40 \times 10^{6} \mathrm{CFU} / \mathrm{g}\right)$ (Figs. 1, 2).

The immune parameters of shrimp were significantly influenced by AX in the shrimp feed. Shrimps fed with diets containing AX (namely, $50 \mathrm{ppm} \mathrm{AX}+0.3 \%$ FA, 50 ppm $\mathrm{AX}+0.6 \%$ FA, and $50 \mathrm{ppm}$ AX) had a total hemocyte count (THC) (Fig. 3), phagocytosis activity (Fig. 4), and phenoloxidase (PO) activity (Fig. 5) significantly higher than the control and the FA groups. Superoxide dismutase (SOD) activity (Fig. 6) of $50 \mathrm{ppm}$ AX-fed shrimps but not the $50 \mathrm{ppm} \mathrm{AX}+0.3 \%$ FA and $50 \mathrm{ppm} \mathrm{AX}+0.6 \%$ FA groups showed a significant increase compared with shrimps that not fed AX. However, the bactericidal activity of the shrimp's hemolymph from all groups was at the same serum dilution, being 1:4 (Additional file 1: Table S3).

\section{Discussion}

Organic acids are widely used as animal food additives and preservatives for preventing food deterioration. As a group these compounds primarily include the saturated straightchain monocarboxylic acids and their derivatives (Ricke 2003). Many of them are available as sodium, potassium, or calcium salts because they are generally odorless, easier to handle, less corrosive, and may have higher solubility than free acids (Papatsiros and Billinis 2012). Organic acids possess antimicrobial activity against several pathogenic

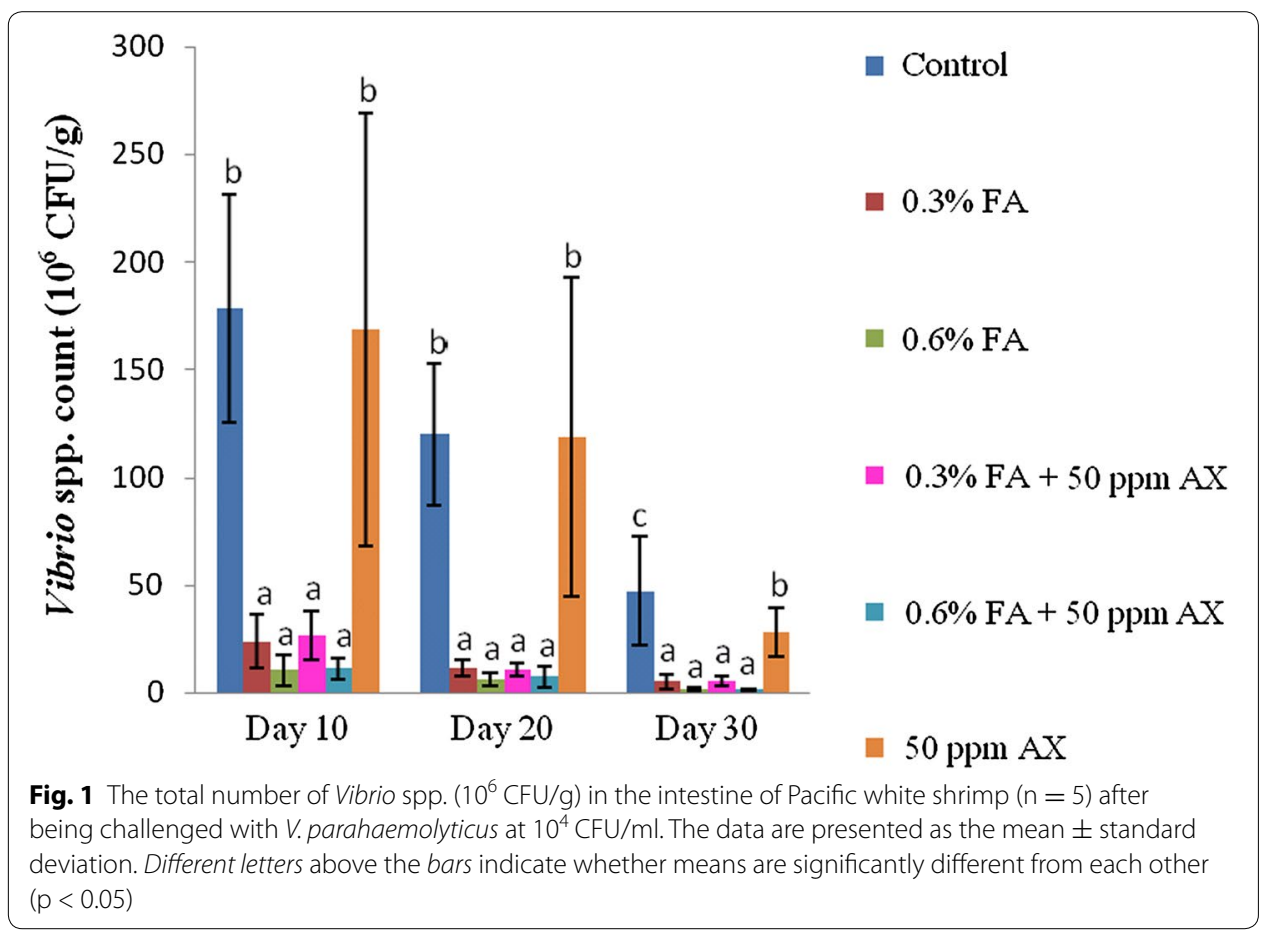



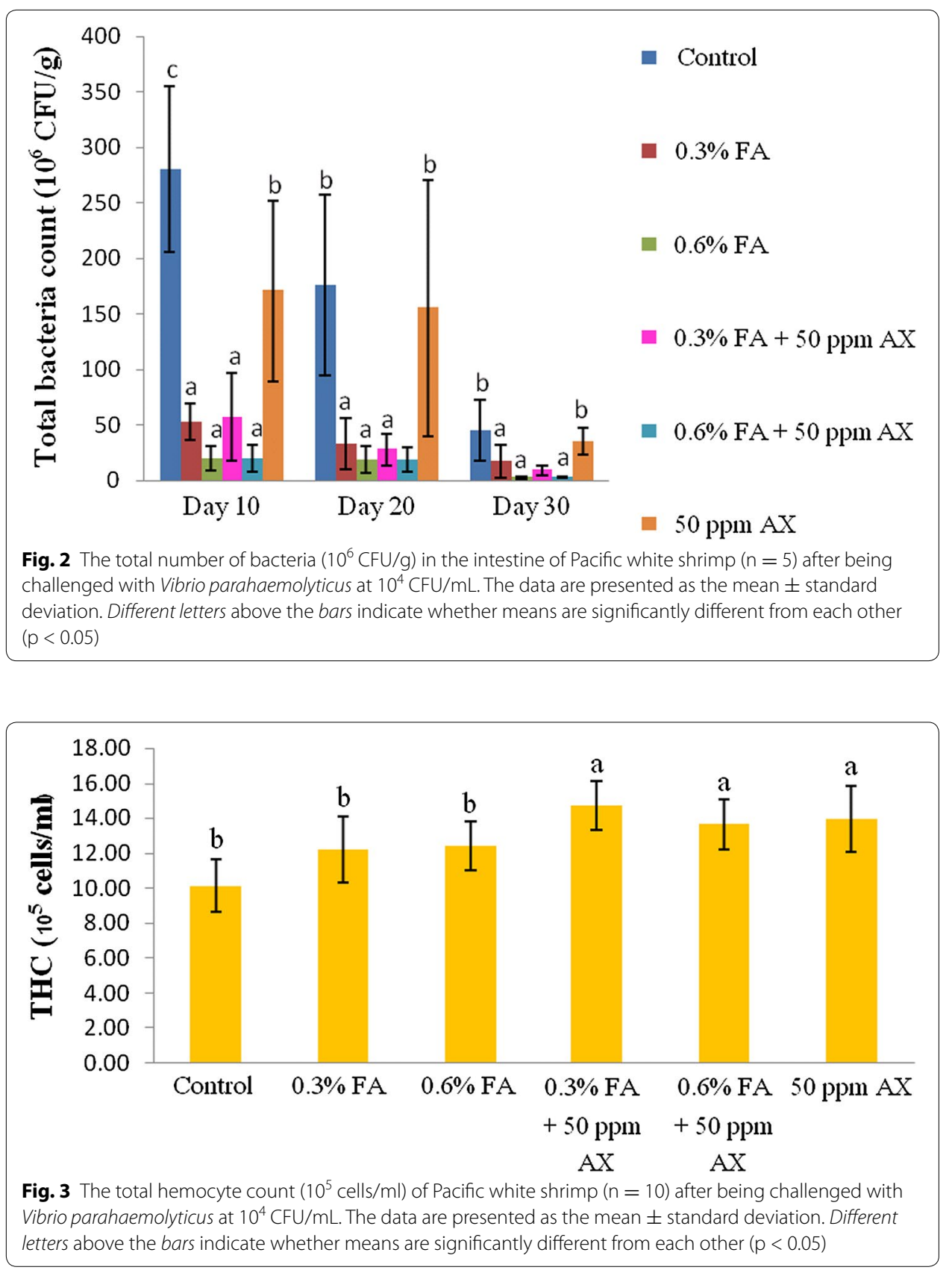

bacteria such as Escherichia coli, Salmonella spp., and Vibrio spp. (Ricke 2003; Papatsiros and Billinis 2012; da Silva et al. 2013). Undissociated forms of organic acids can easily penetrate bacterial cell membranes, and dissociate into anions and $\mathrm{H}^{+}$within the cytoplasm (Ricke 2003; Beales 2004; Lückstädt and Mellor 2011). Once inside the bacterial cells, they reduce intracellular $\mathrm{pH}$ and disrupt the cytoplasmic membrane, protein synthesis system, genetic materials, and metabolic enzymes. In addition, because the bacterial cell uses ATP to pump the excess $\mathrm{H}^{+}$out of cells, organic acids also deplete ATP levels and affect the cell's ability to maintain pH homeostasis (Ricke 2003; Beales 2004; Lückstädt and Mellor 2011). However, not all organic acids have effects on bacteria. In 


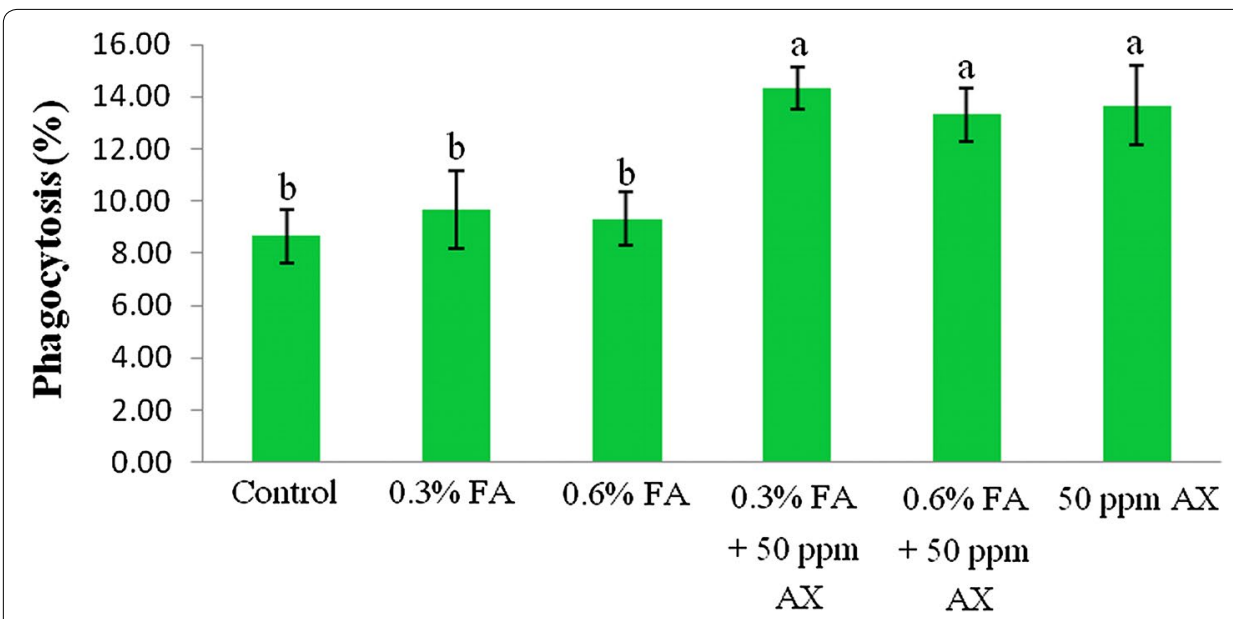

Fig. 4 The phagocytosis activity (\%) of Pacific white shrimp $(n=10)$ after being challenged with Vibrio parahaemolyticus at $10^{4} \mathrm{CFU} / \mathrm{mL}$. The data are presented as the mean \pm standard deviation. Different letters above the bars indicate whether means are significantly different from each other $(p<0.05)$

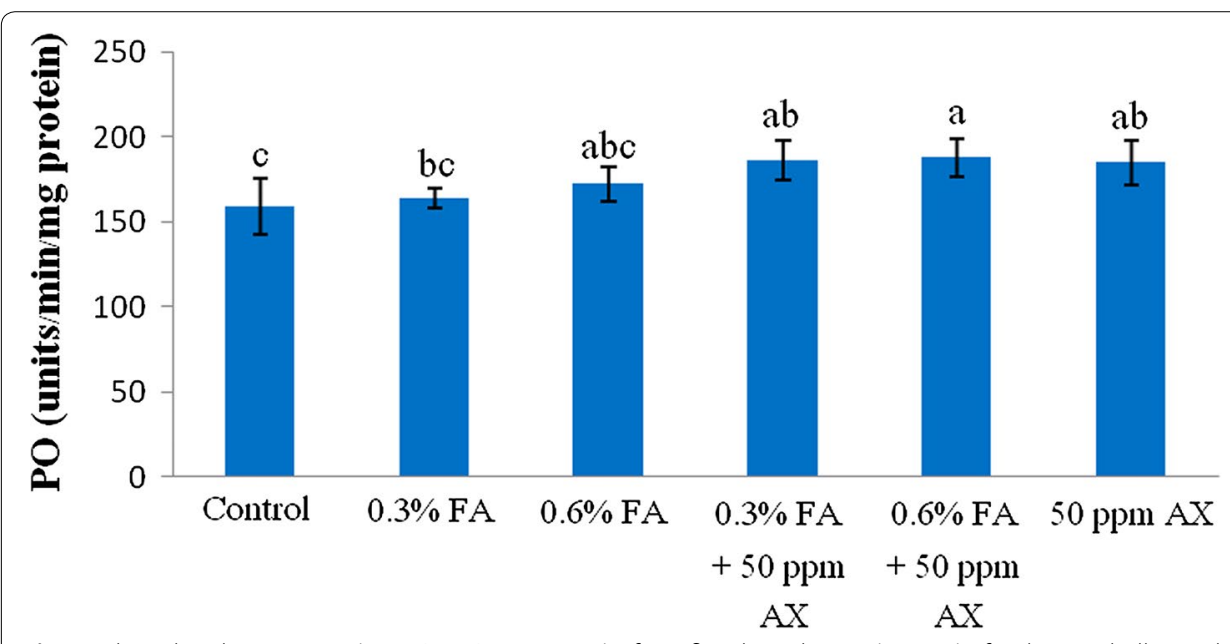

Fig. 5 Phenoloxidase activity (units/min/mg protein) of Pacific white shrimp $(n=10)$ after being challenged with Vibrio parahaemolyticus at $10^{4} \mathrm{CFU} / \mathrm{ml}$. The data are presented as the mean \pm standard deviation. Different letters above the bars indicate whether means are significantly different from each other $(p<0.05)$

fact, organic acids associated with specific antimicrobial activity are short-chain acids (C1-C7) and are either simple monocarboxylic acids such as formic, acetic, propionic, and butyric acid, or are carboxylic acid bearing a hydroxyl group such as lactic, malic, tartaric, and citric acids (Dibner and Buttin 2002; Papatsiros and Billinis 2012).

Organic acids are mainly used as feed additives for improving growth performance of pigs and poultry (Dibner and Buttin 2002; Franco et al. 2005; Lückstädt and Mellor 2011; Papatsiros and Billinis 2012); there are also reports on the benefit of organic acids in aquatic animals, including red hybrid tilapia (Ng et al. 2009; Koh et al. 2014), yellowtail (Sarker et al. 2012), sturgeon (Khajepour and Hosseini 2012), rohu (Baruah et al. 2007), black tiger shrimp (Ng et al. 2015), and Pacific white shrimp (Walla et al. 2012; da Silva et al. 2013; Su et al. 2014; Romano et al. 2015). Nevertheless, the result 


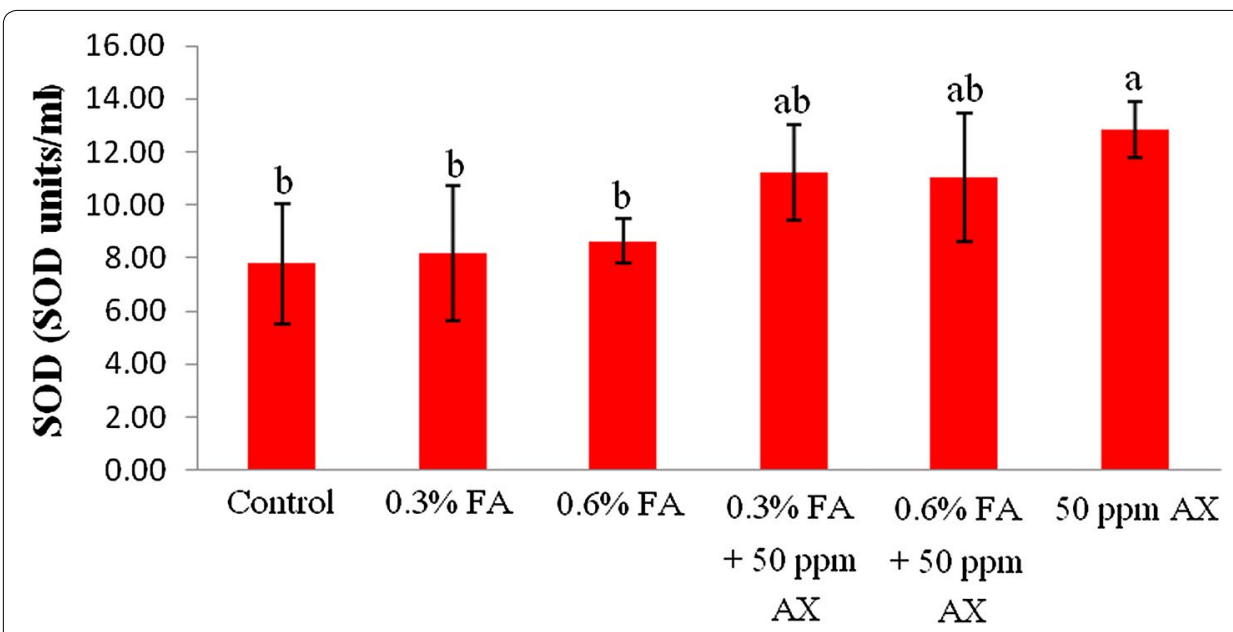

Fig. 6 Superoxide dismutase activity (SOD units $/ \mathrm{mL})$ of Pacific white shrimp $(n=10)$ after being challenged with Vibrio parahaemolyticus at $10^{4} \mathrm{CFU} / \mathrm{ml}$. The data are presented as the mean \pm standard deviation. Different letters above the bars indicate whether means are significantly different from each other $(p<0.05)$

from experiment 1 showed that shrimp fed FA had significantly lower body weight than shrimp fed $50 \mathrm{ppm}$ AX and the growth was slightly less than the control group. This indicated that formic acid did not promote the growth of the shrimp and might have some negative effect on shrimp growth. Other short chain fatty acids may enhance the growth, for example, $2 \%$ organic acids blend (consisted of a blend of formic, lactic, malic and citric acids) (Romano et al. 2015) or $2 \mathrm{~g} / \mathrm{kg}$ citric acid (Su et al. 2014).

Despite no clear improvement of growth and survival of uninfected shrimp postlarvae in our study, the use of formic acid did increase the survival rate of V. parahaemolyticusinfected juvenile shrimps significantly compared with the control group. This result was consistent with the intestinal bacterial study, i.e. shrimp fed formic acid had significantly lower Vibrio spp. and total bacterial counts compared with those fed no formic acid. The similarity between Vibrio spp. counts and total bacterial counts suggested that Vibrio spp. are significant component of shrimp's intestinal microflora (Moss et al. 2000; Oxley et al. 2002; Liu et al. 2011). The antimicrobial effect of formic acid against Vibrio spp. was reported in vitro as well (Mine and Boopathy 2011; Adams and Boopathy 2013; da Silva et al. 2013). Considering all of these aspects, the antibacterial property of formic acid may reduce Vibrio infection to Pacific white shrimp (Papatsiros and Billinis 2012; Adams and Boopathy 2013; da Silva et al. 2013) by penetrating the cell wall of bacteria in the undissociated form, then releasing $\mathrm{H}^{+}$and destabilizing the intracellular $\mathrm{pH}$ of the bacterial cytoplasm, leading to death (da Silva et al. 2013).

Astaxanthin is a pigment that belongs to the xanthophyll class (the oxygenated derivatives of carotenoids) and widely used in salmon and crustacean aquaculture to provide a desirable reddish-orange color. Astaxanthin possesses a potent antioxidant property and has an important role in larval growth and reproductive success of crustaceans. It occurs naturally in green microalgae Haematococcus pluvialis and red yeast Xanthophyllomyces dendrorhous (Phaffia rhodozyma). However, since farmed crustaceans often do not have the opportunity to access a natural source of astaxanthin, and they cannot synthesize 
carotenoids de novo, total astaxanthin must be obtained from their feed (Higuera-Ciapara et al. 2006; Seabra and Pedrosa 2010).

The growth of AX-fed shrimp in the experiment 1 was significantly better than the FAfed shrimp, but was not significantly different from the control group. The survival rate of shrimp fed with AX was not significantly different from the control group. However, the survival rate of $V$. parahaemolyticus-infected shrimp in the experiment 2 was improved significantly. Nevertheless, unlike formic acid, astaxanthin did not suppress intestinal bacterial populations, suggesting that other mechanisms may be responsible for the increased survival rate. In fact, many immune parameters of astaxanthin-fed shrimps were improved, including total hemocyte count (THC), phagocytosis activity, phenoloxidase (PO) activity, and superoxide dismutase (SOD) activity. These outcomes suggest that astaxanthin had an immunostimulatory property preventing $V$. parahaemolyticus infection in Pacific white shrimp. Antioxidant activity of carotenoids may be involved in the immunomodulatory effect; by quenching singlet oxygen and free radicals, carotenoids can protect white blood cells from oxidative damage (Bendich 1989). Superoxide dismutase (SOD) is an antioxidant enzyme that protect cells against oxidative stress by scavenges superoxide anion $\left(\mathrm{O}_{2}{ }^{-}\right)$and it is used as an indicator of immune responses (Campa-Córdova et al. 2002a, 2002b). Given that astaxanthin also possesses an antioxidant property, this is suggests that such mechanism must be take part in immunomodulation. Furthermore, the effects of carotenoids on enhancing cell-mediated and humoral immune responses of vertebrates are also documented (Bendich 1989; Chew and Park 2004). Several studies have reported that dietary carotenoids can increase the immune parameters, enhance the survival rate, or act as a prophylactics to pathogens for many aquatic animals such as common carp (Anbazahan et al. 2014; Sowmya and Sachindra 2015), rainbow trout (Amar et al. 2001), Pacific white shrimp (Flores et al. 2007; Niu et al. 2009), black tiger shrimp (Supamattaya et al. 2005), kuruma prawn (Chien and Shiau 2005), and giant freshwater prawn (Angeles et al. 2009). Our results are somewhat similar to these studies.

Even if formic acid and astaxanthin have different modes of action to shrimp, both had positive effects on their resistance to bacterial challenge. Meanwhile, our results showed that a combination of formic acid and astaxanthin was no better than using singly or in combination. The only exception was that uninfected shrimp fed $0.6 \%$ FA $+50 \mathrm{ppm}$ AX had a significantly higher survival rate compared with the control group. In general, formic acid (FA 0.3 and $0.6 \%$ ) and astaxanthin (50 ppm AX) were equally effective in preventing $V$. parahaemolyticus infection of Pacific white shrimp. Given the fact that formic acid is less expensive than astaxanthin, using formic acid as feed additive in shrimp farming may be considered more economically worthwhile.

\section{Conclusion}

Astaxanthin (50 ppm AX) can be used as growth promoter in uninfected Pacific white shrimp, while formic acid ( 0.3 and $0.6 \%$ FA) and AX can enhance the survival rate of Vibrio parahaemolyticus-infected shrimp in laboratory conditions. In addition, FA-fed shrimps had lower intestinal Vibrio spp. and total bacterial counts, whereas AX-fed shrimps showed improvement in many immune parameters. The results of our study suggest that using FA, AX, and their combination as a feed additive can prevent $V$. parahaemolyticus infection in shrimps. 


\section{Additional file}

Additional file 1. Table S1. The body weight and survival rate of Pacific white shrimp after 60 day of dietary administration. Table S2. The body weight and survival rate of Pacific white shrimp at 30 day after being challenged with Vibrio parahaemolyticus $10^{4} \mathrm{CFU} / \mathrm{ml}$. Table S3. The bactericidal activity of the shrimp's hemolymph from all groups.

\section{Authors' contributions}

NC designed and supervised the study and proofreading of the manuscript. PR performed the experiment and analyzed data. TR analyzed data and drafted the manuscript. All authors read and approved the final manuscript.

\section{Acknowledgements}

The authors would like to thank BASF, Germany, for financial support

\section{Compliance with ethical guidelines}

\section{Competing interests}

The authors declare that they have no competing interests.

Received: 27 February 2015 Accepted: 11 August 2015

Published online: 21 August 2015

\section{References}

Adams D, Boopathy R (2013) Use of formic acid to control vibriosis in shrimp aquaculture. Biologia 68(6):1017-1021 Amar EC, Kiron V, Satoh S, Watanabe T (2001) Influence of various dietary synthetic carotenoids on bio-defence mechanisms in rainbow trout, Oncorhynchus mykiss (Walbaum). Aquacult Res 32:162-173

Anbazahan SM, Mari LS, Yogeshwari G, Jagruthi C, Thirumurugan R, Arockiaraj J, Velanganni AA, Krishnamoorthy P, Balasundaram C, Harikrishnan R (2014) Immune response and disease resistance of carotenoids supplementation diet in Cyprinus carpio against Aeromonas hydrophila. Fish Shellfish Immunol 40(1):9-13

Angeles IP, Chien YH, Tayamen MM (2009) Effects of different dosages of astaxanthin on giant freshwater prawn Macrobrachium rosenbergii (De Man) challenged with Lactococcus garvieae. Aquacult Res 41(1):70-77

Baruah K, Sahu PN, Pal AK, Jain KK, Debnath D, Mukherjee SC (2007) Dietary microbial phytase and citric acid synergistically enhances nutrient digestibility and growth performance of Labeo rohita (Hamilton) juveniles at sub-optimal protein level. Aquacult Res 38(2):109-120

Beales N (2004) Adaptation of microorganisms to cold temperatures, weak acid preservatives, low pH, and osmotic stress: a review. Compr Rev Food Sci F 3(1):1-20

Bendich A (1989) Carotenoids and the immune response. J Nutr 119(1):112-115

Campa-Córdova Al, Hernández-Saavedra NY, Ascencio F (2002a) Superoxide dismutase as modulator of immune function in American white shrimp (Litopenaeus vannamei). Comp Biochem Physiol C Toxicol Pharmacol 133(4):557-565

Campa-Córdova Al, Hernández-Saavedra NY, De Philippis R, Ascencio F (2002b) Generation of superoxide anion and SOD activity in haemocytes and muscle of American white shrimp (Litopenaeus vannamei) as a response to beta-glucan and sulphated polysaccharide. Fish Shellfish Immunol 12(4):353-366

Chew BP, Park JS (2004) Carotenoid action on the immune response. J Nutr 134(1):257S-261S

Chien YH, Shiau WC (2005) The effects of dietary supplementation of algae and synthetic astaxanthin on body astaxanthin, survival, growth, and low dissolved oxygen stress resistance of kuruma prawn, Marsupenaeus japonicus Bate. J Exp Mar Biol Ecol 316(2):201-211

Chien YH, Pan CH, Hunter B (2003) The resistance to physical stresses by Penaeus monodon juveniles fed diets supplemented with astaxanthin. Aquaculture 216(1-4):177-191

da Silva BC, Vieira FN, Mouriño JLP, Ferreira GS, Seiffert WQ (2013) Salts of organic acids selection by multiple characteristics for marine shrimp nutrition. Aquaculture 384-387:104-110

Dibner JJ, Buttin P (2002) Use of organic acids as a model to study the impact of gut microflora on nutrition and metabolism. J Appl Poult Res 11:453-463

Flores M, Díaz F, Medina R, Re AD, Licea A (2007) Physiological, metabolic and haematological responses in white shrimp Litopenaeus vannamei (Boone) juveniles fed diets supplemented with astaxanthin acclimated to low-salinity water. Aquacult Res 38(7):740-747

Franco LD, Fondevila M, Lobera MB, Castrillo C (2005) Effect of combinations of organic acids in weaned pig diets on microbial species of digestive tract contents and their response on digestibility. J Anim Physiol Anim Nutr (Berl) 89(3-6):88-93

Higuera-Ciapara I, Félix-Valenzuela L, Goycoolea FM (2006) Astaxanthin: a review of its chemistry and applications. Crit Rev Food Sci Nutr 46(2):185-196

Itami T, Takahashi Y, Tsuchihira E, Igasu H, Kondo M (1994) Enhancement of disease resistance of kuruma prawn Penaeus japonicus and increase in phagocytic activity of prawn hemocytes after oral administration of $\beta$ 1,3-glucan (Schizophyllan). In: The Asian Fisheries Society Manila, Philippines, 26-30 October 1992

Joshi J, Srisala J, Truong VH, Chen I, Nuangsaeng B, Suthienkul O, Lo CF, Flegel TW, Sritunyalucksana K, Thitamadee S (2014) Variation in Vibrio parahaemolyticus isolates from a single Thai shrimp farm experiencing an outbreak of acute hepatopancreatic necrosis disease (AHPND). Aquaculture 428-429:297-302 
Khajepour F, Hosseini SA (2012) Citric acid improves growth performance and phosphorus digestibility in Beluga (Huso huso) fed diets where soybean meal partly replaced fish meal. Anim Feed Sci Technol 171(1):68-73

Koh CB, Romano N, Zahrah AS, Ng WK (2014) Effects of a dietary organic acids blend and oxytetracycline on the growth, nutrient utilization and total cultivable gut microbiota of the red hybrid tilapia, Oreochromis sp., and resistance to Streptococcus agalactiae. Aquacult Res. doi:10.1111/are.12492 (in press)

Lavilla-Pitogo CR, Leano EM, Paner MG (1998) Mortalities of pond-cultured juvenile shrimp, Penaeus monodon, associated with dominance of luminescent vibrios in the rearing environment. Aquaculture 164:337-349

Limsuwan C, Chanratchakool P (2004) Shrimp aquaculture industries of Thailand. National Research Council of Thailand, Bangkok

Liu H, Wang L, Liu M, Wang B, Jiang K, Ma S (2011) The intestinal microbial diversity in Chinese shrimp (Fenneropenaeus chinensis) as determined by PCR-DGGE and clone library analyses. Aquaculture 317:32-36

Lowry OH, Rosebrough NJ, Farrand AL, Randall RJ (1951) Protein measurement with the folin phenol reagent. J Biol Chem 193:265-275

Lückstädt C, Mellor S (2011) The use of organic acids in animal nutrition, with special focus on dietary potassium diformate under European and Austral-Asian conditions. Recent Adv Anim Nutr Aust 18:123-130

Mine S, Boopathy R (2011) Effect of organic acids on shrimp pathogen, Vibrio harveyi. Curr Microbiol 63(1):1-7

Moss S, LeaMaster B, Sweeney J (2000) Relative abundance and species composition of Gram-negative, aerobic bacteria associated with the gut of juvenile white shrimp Litopenaeus vannamei reared in oligotrophic well water and eutrophic pond water. J World Aquac Soc 31:255-263

Munkongwongsiri N, Limsuwan C, Chuchird N (2013) Effects of postlarval quality on occurrence of Early Mortality Syndrome in Litopenaeus vannamei culture ponds. In: Proceeding of 51th Kasetsart University Annual Conference, Fisheries section, Kasetsart University, Bangkok, Thailand, 5-7 February 2013

$\mathrm{Ng}$ WK, Koh CB, Sudesh K, Siti-Zahrah A (2009) Effects of dietary organic acids on growth, nutrient digestibility and gut microflora of red hybrid tilapia, Oreochromis sp., and subsequent survival during a challenge test with Streptococcus agalactiae. Aquacult Res 40(13):1490-1500

Ng WK, Koh CB, Teoh CY, Romano N (2015) Farm-raised tiger shrimp, Penaeus monodon, fed commercial feeds with added organic acids showed enhanced nutrient utilization, immune response and resistance to Vibrio harveyi challenge. Aquaculture. doi:10.1016/j.aquaculture.2015.02.006 (in press)

Niu J, Tian LX, Liu YJ, Yang HJ, Ye CX, Gao W, Mai KS (2009) Effect of dietary astaxanthin on growth, survival, and stress tolerance of postlarval shrimp, Litopenaeus vannamei. J World Aquacul Soc 40(6):795-802

Nonwachai T, Purivirojkul W, Limsuwan C, Chuchird N, Velasco M, Dhar AK (2010) Growth, nonspecific immune characteristics, and survival upon challenge with Vibrio harveyi in Pacific white shrimp (Litopenaeus vannamei) raised on diets containing algal meal. Fish Shellfish Immunol 29(2):298-304

Office of Agricultural Economics (2014) Situation of important agricultural products and trends in 2015. Office of Agricultural Economics, Ministry of Agriculture and Cooperatives, Bangkok, Thailand (in Thai)

Oxley A, Shipton W, Owens L, McKay D (2002) Bacterial flora from the gut of the wild and cultured banana prawn, Penaeus merguiensis. J Appl Microbiol 93:214-223

Pan CH, Chien YH, Hunter B (2003) The resistance to ammonia stress of Penaeus monodon Fabricius juvenile fed diets supplemented with astaxanthin. J Exp Mar Biol Ecol 297(1):107-118

Papatsiros G, Billinis C (2012) The prophylactic use of acidifiers as antibacterial agents in swine. In: Bobbarala V (ed) Antimicrobial agents. InTech, Rijeka, Croatia

Ricke SC (2003) Perspectives on the use of organic acids and short chain fatty acids as antimicrobials. Poult Sci 82(4):632-639

Romano N, Koh CB, Ng WK (2015) Dietary microencapsulated organic acids blend enhances growth, phosphorus utilization, immune response, hepatopancreatic integrity and resistance against Vibrio harveyi in white shrimp, Litopenaeus vannamei. Aquaculture 435:228-236

Sarker MSA, Satoh S, Kamata K, Haga Y, Yamamoto Y (2012) Supplementation effect(s) of organic acids and/or lipid to plant protein-based diets on juvenile yellowtail, Seriola quinqueradiata Temminck et Schlegel 1845, growth and nitrogen and phosphorus excretion. Aquacult Res 43(4):538-545

Seabra LMJ, Pedrosa LFC (2010) Astaxanthin: structural and functional aspects. Rev Nutr 23(6):1041-1050

Sowmya R, Sachindra NM (2015) Enhancement of non-specific immune responses in common carp, Cyprinus carpio, by dietary carotenoids obtained from shrimp exoskeleton. Aquacult Res 46(7):1562-1572

Su X, Li X, Leng X, Tan C, Liu B, Chai X, Guo T (2014) The improvement of growth, digestive enzyme activity and disease resistance of white shrimp by the dietary citric acid. Aquacult Int 22:1823-1835

Sung HH, Hsu SF, Chen CK, Ting YY, Chao WL (2001) Relationships between disease outbreak in cultured tiger shrimp (Penaeus monodon) and the composition of Vibrio communities in pond water and shrimp hepatopancreas during cultivation. Aquaculture 192:101-110

Supamattaya K, Pongmaneerat J, Klowklieng T (2000) The effect of $\beta$-glucan (MacroGard ${ }^{\circledR}$ ) on growth performance, immune response and disease resistance in black tiger shrimp, Penaeus monodon Fabricius. Songklanakarin J Sci Technol 22:677-688

Supamattaya K, Kiriratnikom S, Boonyaratpalin M, Borowitzka L (2005) Effect of a Dunaliella extract on growth performance, health condition, immune response and disease resistance in black tiger shrimp (Penaeus monodon). Aquaculture 248(1-4):207-216

Tangtong R (2015) Fishery and aquatic animal product. J Agric Econ 61:42-47 (in Thai)

Tran L, Nunan L, Redman RM, Mohney LL, Pantoja CR, Fitzsimmons K, Lightner DV (2013) Determination of the infectious nature of the agent of acute hepatopancreatic necrosis syndrome affecting penaeid shrimp. Dis Aquat Organ 105(1):45-55

Walla W, Purivirojkul W, Chuchird N, Limsuwan C (2012) Effects of activate DA on growth, survival and the total number of bacteria and Vibrio spp. in rearing of pacific white shrimp (Litopenaeus vannamei). KU Fish Res Bull 36(2):14-22 